\title{
Bolnav cu Gist Gastric Gigant; Supraviețuire Nesperată Prezentare de Caz
}

\author{
M Gheorghe ${ }^{1}$, D Predescu ${ }^{1}$, N Copca $^{2}$, Cristina losif ${ }^{3}$, F Băcanu ${ }^{4}$ and S Constantinoiu ${ }^{1}$ \\ ${ }^{1}$ Clinica de Chirurgie Generală și Esofagiană, Spitalul Clinic Sfânta Maria București, Universitatea de Medicină și Farmacie Carol Davila” București, Romania \\ ${ }^{2}$ Centrul de Cercetare Chirurgie, Spitalul Clinic Sfânta Maria București, Universitatea de Medicină și Farmacie Carol Davila” București, Romania \\ ${ }^{3}$ Departamentul de Anatomie Patologică, Spitalul Clinic Sfânta Maria București, Universitatea de Medicină și Farmacie Carol Davila" București, Romania \\ ${ }^{4}$ Departamentul de Oncologie, Spitalul Clinic Sfânta Maria București, Universitatea de Medicină și Farmacie Carol Davila” București, Romania
}

"Correspondence author: Mircea Gheorghe, MD, Department of General and Esophagian Surgery, "St. Mary" Hospital București, Bd. Ion Mihalache, No 37-39, Sector 1, București, Romania, Tel: +40 (0) 7212260 20; Fax:0040721226020; E-mail: rgheorghemircea@yahoo.com

Received date: 10 November.2013; Accepted date: 27 February.2014; Published date: 9 May 2014

Copyright: (c) 2014 Gheorghe M, et al. This is an open-access article distributed under the terms of the Creative Commons Attribution License, which permits unrestricted use, distribution, and reproduction in any medium, provided the original author(s) and source are credited.

\begin{abstract}
Background: Gastrointestinal Stromal Tumors (GIST) are rare neoplasms, with sever prognosis in advanced cases. Until the discovery of Tyrosin Kinase Inhibitors (TKI), the life expectancy was very poor for patient with metastatic tumors, postoperative relapses or unresectable disease. Introduction of TKI therapy provided an unexpected survival rate, controlling the disease with very good tolerance.

Method: We present a case report representative for GIST pathology. It is the first case of our GIST series of patients, operated in General and Esophageal Surgery Clinic of "St. Mary" Hospital Bucharest. A multidisciplinary approach and a complex, multimodal, surgical and oncological treatment was applied, with good response confirmed by the long-term follow-up. A 79 years old patient was diagnosed in 2004 (at the age of 70 years) with giant gastric GIST. He underwent a total gastrectomy, splenectomy and left pancreatectomy; the resection was considered as R1 because the tumor capsule was not complete. The adjuvant treatment with TKI was started postoperatively for 2 years. The recurrence was noted one year after the adjuvant therapy stop. Then the TKI treatment was restarted with very good tolerance and control of disease at 9 years.
\end{abstract}

Conclusion: The TKI therapy allows long-term control of the malignant GISTs in term of overall survival and quality of life, even when the surgical procedure is not optimal.

Keywords: Gastro-Intestinal Stromal Tumors; Malignant; Gastric Gist; Gastrectomy; Tyrosin Kinase Inhibitot; Imatinib Mesylate; Survival

\section{Introducere}

Tumorile stromale gastrointestinale (Gastro-Intestinal Stromal Tumors - GIST), sunt descoperiri rare, cu un prognostic sever în cazurile avansate. Până la descoperirea inhibitorilor de tirozin kinază (ITK), pentru pacienții cu tumori metastatice, cu recidive postoperatorii precum și cu tumori nerezecabile, speranța de viață era foarte redusă. Introducerea ITK (de ex. Imatinib mesilat) a permis controlul bolii și prelungirea nesperată a supraviețuirii [1].

În lucrarea de față prezentăm primul pacient cu GIST gastric operat în clinică, un caz particular prin faptul că a prezentat o tumora gigantă gastrică ce a necesitat un abord multidiciplinar și un tratament complex, chirurgical și oncologic, care i-au asigurat o supraviețuire nesperată de 9 ani de la momentul diagnosticului.

\section{Prezentare De Caz}

Pacient de 70 de ani, obez, (indice de masă corporală (IMC) de 34,8 $\mathrm{kg} / \mathrm{m}^{2}$ ), hipertensiv, se prezintă în noiembrie 2004 pentru disconfort epigastric, scăderea apetitului alimentar, scădere în greutate de circa 5 $\mathrm{kg}$ în ultimele 2 luni și astenie fizică.
Examenul clinic identifică la nivel abdominal o formațiune tumorală palpabilă în epigastru. Examenele de laborator la internare au fost în limite relativ normale.

Endoscopia digestivă evidențiază o ulcerație gastrică localizată pe marea curbură gastrică; biopsiile au fost neconcludente.

Computer tomografia abdomino-pelvină confirmă prezența în etajul supramezocolic a unei formațiuni tumorale voluminoase, $\mathrm{cu}$ structură neomogenă, a cărei apartenență de organ nu poate fi precizată, cu compresia organelor cavitare din jur: stomac, colon transvers și invazia pancreasului și a hilului splenic. $\mathrm{Nu}$ se constată determinări secundare hepatice, sau limfoganglionare vizibile tomografic.

Se intervine chirurgical și se constată: tumoră gigantă gastrică, cu invazia pancreasului corporeo-caudal și a splinei. Se practică gastrectomie totală, pancreatectomie corporeo-caudală, splenectomie și refacerea continuității digestive prin anastomoză eso-jejunală pe ansă în " $\Omega$ ". Rezecția a fost apreciata R1 deoarece, datorită volumului tumoral, în cursul mobilizării tumorale se descriu câteva mici efracții ale capsulei tumorale (Figure 1). 


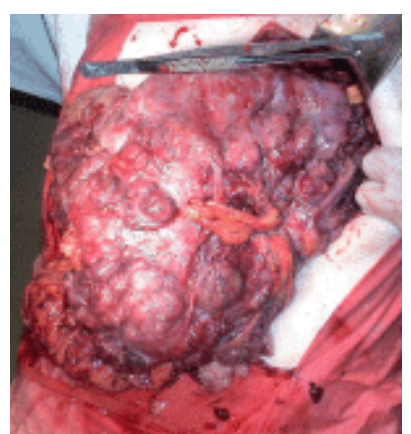

Figure 1: Formațiunea tumorală; aspect intraoperator.

Examenul histopatologic al piesei operatorii confirmă prezența unei tumori de 29 × $20 \mathrm{~cm}$ cu zone de necroză, ce înglobează corpul gastric și corpul pancreasului; sunt confirmate efracțiile de la nivelul capsulei. Microscopia (Figure 2) confirmă prezența celulelor de tip "spindlecell" care, imunohistochimic, exprimă CD-117 (c-Kit) (Figure 3) și CD-34. Analiza mutațională evidențiază deleție la nivelul exonului 11.

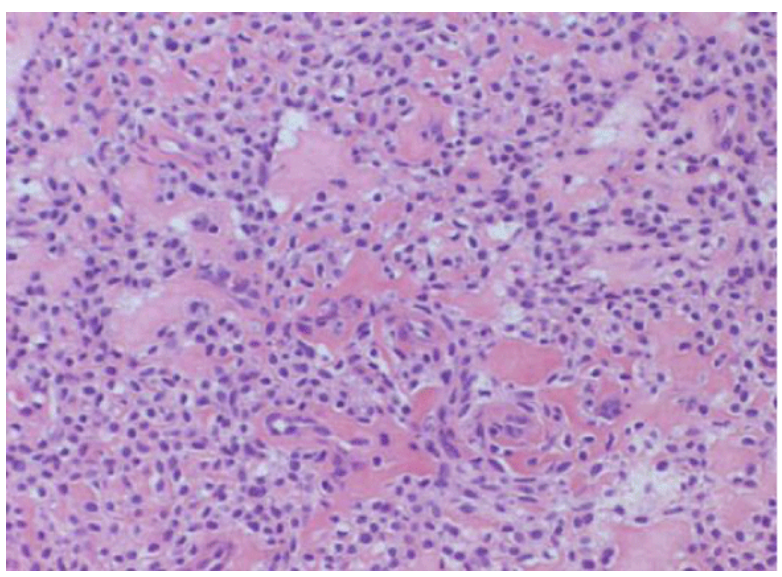

Figure 2: Microscopie (HE 10x): tumoră cu cellule de tip "spindle cell".

Prin utilizarea criteriilor histologice de stratificare a riscului de progresie a bolii, sediul tumorii, dimensiunea tumorală și numărul de mitoze identificate prin examenul anatomopatologic tumora este apreciată ca GIST cu grad ridicat al riscului de recidivă $(>86 \%)$ și pacientul este inclus într-un proiect de cercetare al CECOG (Central European Cooperative Oncology Group) și primește Imatinib mesilat timp de 2 ani, fiind urmărit clinico-paraclinic pe întreaga perioadă a trialului clinic.

Urmarirea periodică prin examen CT nu evidențiază urme de recidivă intra-abdominală sau metastaze hepatice.

După părăsirea programului amintit, la 1 an de la întreruperea tratamentului, pacientul revine în clinică pentru controlul periodic și prezintă două recidive intra-abdominale, una dintre ele palpabilă la nivel paraombilical stâng, formațiuni evidente la computer tomografie (CT) și confirmate prin examen PET-CT FDG (Figure 4).

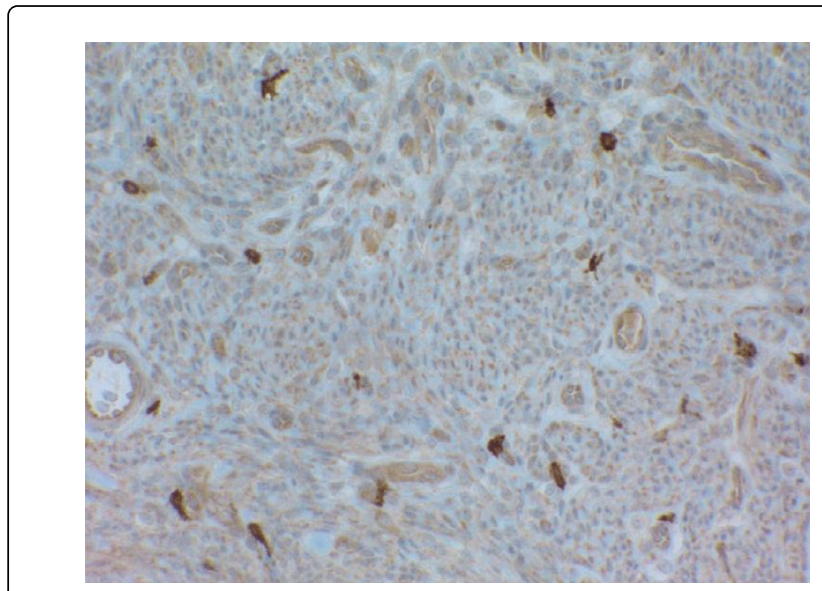

Figure 3: Imunihistochimie: celule positive la markajul CD-117.
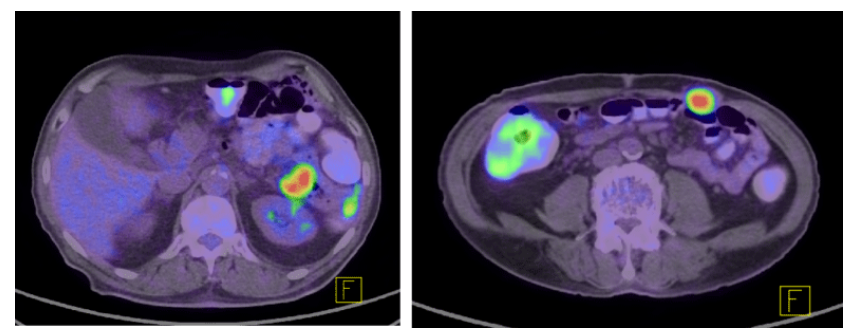

Figure 4: PET-CT: recidive abdominale cu localizare intraabdominală și parietală.
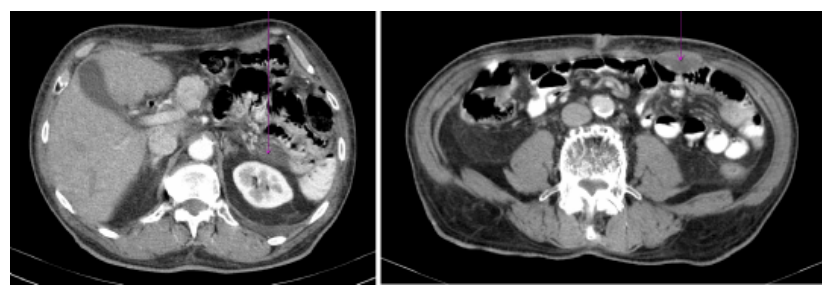

Figure 5: Examen CT: aspect stabil al recidivelor abdominale în cursul tratamentului cu ITK.

Pacientul reîncepe tratamentul cu Imatinib mesilat, 400mg/zi, iar controalele efectuate la un interval de 3 luni demonstrează un bun răspuns cu reducerea dimensiunilor tumorale, precum și o bună toleranță la tratament (Figure 5).

La ultimul control din octombrie 2013 pacientul este asimptomatic la nivel abdominal, fără nicio dificultate în efectuarea activităților zilnice și fără efecte secundare ale chimioterapiei.

\section{Discuții}

GIST reprezintă o forma rară de sarcom care ia naștere din celulele intersițiale Cajal sau din celulele stem nediferențiate, localizate în tunica musculară a tractului gastrointestinal. GIST poate afecta orice segment de tub digestiv dar apare cu predilecție la nivelul stomacului 
$60 \%$, intestinului subțire $30 \%$, duodenului $4-5 \%$, rectului $4 \%$, colonului și apendicelui 1-2\% esofagului < 1\%. [1] Foarte rar au fost descrise și GIST-uri extragastrointestinale [2]. Incidența a fost estimata la $1.5 / 100000$ pe an [3]

Din punct de vedere imunohistochimic majoritatea GIST sunt pozitive pentru antigenul c-Kit (CD-117), DOG1, CD-34 și PCKO. Majoritatea GIST prezintă mutaţii genetice la nivelul genelor pentru receptorii KIT și PDGFR, ce au ca rezultat proliferarea tumorală dar în același timp oferă ținte moleculare specifice pentru tratamente de tip ITK. Pentru GIST localizate tratamentul principal este cel chirurgical.

În ciuda eficacității tratamentelor, supraviețuirea pe termen lung nu este satisfăcătoare pentru toți pacienții, datorită pe de o parte

Table I: Factori prognostici pentru GIST. rezistenței la tratament, primare sau secundare, sau pe de altă parte, efectelor adverse ce determină o slabă complianță la tratament.

Mai multe criterii au fost selectate și corelate cu prognosticul și supraviețuirea: localizarea tumorală, mărimea tumorii, activitatea mitotică, necroza tumorală, procentul de celule proliferative, caracterul invaziv, prezența simptomelor, tipul histologic, profilul imunohistochimic, prezența metastazelor sau rezecția R0 fără efracția capsulei tumorale. Miettinen și colab. [1] propun ca factori predictivi ai progresiei tumorale: localizarea, diametrul tumorii și numarul de mitoze și stratifică riscul de recidivă în patru grade (Table 1).

pacienții cu exon 9 mutat, întâlnit la cei cu localizare intestinală sunt mai puțin sensibili, doza necesară fiind dublă [7], fapt demonstrat și de evoluția cazului prezentat care avea o deleție 1 anivelul exonului 11 și a răspuns la tratamentul cu imatinib.

\begin{tabular}{|c|c|c|c|c|}
\hline Categorie de risc & Mărime tumorală $(\mathrm{cm})$ & $\mathrm{Nr}$ de mitoze/50 HPF & Sediu tumoral & Risc de recădere \% \\
\hline Foarte scăzut & $<2$ & $\leq 5$ & oricare & 0 \\
\hline Scăzut & $\begin{array}{l}2-5 \\
5-10 \\
<2\end{array}$ & $\begin{array}{l}\leq 5 \\
\leq 5 \\
>5\end{array}$ & $\begin{array}{l}\text { oricare } \\
\text { stomac } \\
\text { stomac }\end{array}$ & $\begin{array}{l}1,9-4,3 \\
9,6 \\
0\end{array}$ \\
\hline Intermediar & $\begin{array}{l}>10 \\
2-5 \\
5-10\end{array}$ & $\begin{array}{l}\leq 5 \\
>5 \\
\leq 5\end{array}$ & $\begin{array}{l}\text { stomac } \\
\text { stomac } \\
\text { intestin }\end{array}$ & $\begin{array}{l}12 \\
16 \\
24\end{array}$ \\
\hline Înalt & $\begin{array}{l}>10 \\
<2 \\
2-5 \\
5-10 \\
>10\end{array}$ & $\begin{array}{l}\leq 5 \\
>5 \\
>5 \\
>5 \\
>5\end{array}$ & $\begin{array}{l}\text { intestin } \\
\text { intestin } \\
\text { intestin } \\
\text { oricare } \\
\text { oricare }\end{array}$ & $\begin{array}{l}52 \\
50 \\
73 \\
55-85 \\
86-90\end{array}$ \\
\hline
\end{tabular}

Berzi și colab. [4] afirmă după analiza a 158 de cazuri că doar $12 \%$ dintre pacienții cu mitoze $>10 / 50$ HPF (high power fields) rămân vindecați (disease free) după chirurgie, în timp ce toți pacienții cu mitoze >20/50 HPF prezintă recurența bolii. Ei argumenteză că dacă numărul de mitoze și mărimea tumorală situează cazul în grupul de risc înalt, atunci numărul de mitoze devine variabila mai precisă.

Stratificarea riscului include și alți factori independenți cum ar fi: statusul marginilor de rezecție, ruptura tumorală sau statusul mutațional. Ruptura tumorală pre sau intraoperatorie este un factor de prognostic negativ care depășește ceilalți parametri amintiți, situând pacientul în clasa de risc foarte înalt, fapt demonstrat și de evoluția cazului nostru, în timp ce statusul mutațional nu a fost încă introdus în nicio clasificare de risc deși anumite genotipuri de GIST au un comportament patologic specific.

Imatinib mesilatul este primul tratament eficace în GIST. Este indicat ca tratament standard pentru GIST nerezecabil sau metastatic și de asemenea, pentru GIST operat, cu risc moderat sau înalt de recidivă sau pentru pacienții cu recidive postoperatorii ce nu mai sunt candidaţi la tratamentul chirurgical [5].

Imatinib mesilat acționează prin blocarea activării intracelulare produse de receptorii Kit sau PDGFRA, blocând legarea acestora de ATP și prevenind declanșarea semnalelor de creștere celulară, ceea ce oprește progresia bolii. Răspunsul la tratament este legat de tipul mutației la nivelul exonului c-Kit. Pacienții cu mutații la nivelul exonului 11 sunt mai sensibili la imatinib $400 \mathrm{mg} / z i$ [6], în timp ce
Tratamentul trebuie asigurat pe o durată nedeterminată, întreruperea fiind urmată relativ rapid de progresie tumorală în aproape toate cazurile considerate cu risc înalt [8].

În ultima perioadă numeroase lucrări subliniază rolul predictiv al mutațiilor genetice din GIST privind recurența bolii. S-au identificat mutații specifice ale exonului 11 asociate $c u$ rata ridicată de metastazare și prognostic slab. Câteva lucrări subliniază că pacienții cu deleții la nivelul exonului 11, au probabilitate mai mare de a prezenta recurențe sau metastaze decât cei cu substituții sau duplicații la acest nivel $[9,10]$. Aceste date sunt în concordanță cu observația prezentată. Analiza mutațională ar putea deci oferi un algoritm de identificare a pacienților ce necesită pe de o parte o monitorizare mai atentă pentru a identifica recurența bolii dar și un tratament adjuvant pentru a preveni recurențele. De altfel, ultimele conferințe de consens recomandă utilizarea analizei mutaționale pentru o caracterizare mai precisă a GIST-urilor în ceea ce privește riscul de recurență și răspunsul la tratamentul cu inhibitori de c-Kit [11].

În ceea ce privește urmărirea pacienților, o monitorizare atentă trimestrială este necesară pe toată perioada tratamentului adjuvant datorită riscului de recurență/progresie. Totuși în caz de răspuns favorabil la ITK monitorizarea poate fi decalată de la 3 la 6 luni, mai ales după 5 ani de răspuns pozitiv, persistent, la tratament, deoarece există date care sugereaza scăderea riscului de recidivă în timp [11]. 


\section{Concluzii}

Lucrarea demonstrează eficacitatea și siguranța tratamentului cu imatinib în controlul progresiei bolii. Analiza mutațională reprezintă o etapă obligatorie pentru evaluarea prognosticului şi răspunsului la tratamentul cu ITK.

\section{Conflict De Interese}

Autorii nu declară niciun conflict de interese.

\section{Bibliografie}

1. Miettinen M, Lasota J (2006) Gastrointestinal stromal tumors: pathology and prognosis at different sites. Semin Diagn Pathol 23: 70-83.

2. Alkhatib L, Albtoush O, Bataineh N, Gharaibeh K, Matalka I, et al. (2011) Extragastrointestinal Stromal Tumor (EGIST) in the abdominal wall: Case report and literature review. Int J Surg Case Rep 2: 253-255.

3. Gatta G, van der Zwan JM, Casali PG, Siesling S, Dei Tos AP, et al. (2011) Rare cancers are not so rare: the rare cancer burden in Europe. Eur J Cancer 47: 2493-2511.

4. Bearzi I, Mandolesi A, Arduini F, Costagliola A, Ranaldi R. Gastrointestinal stromal tumor. A study of 158 cases: clinicopathological features and prognostic factors. Anal Quant Cytol Histol. 2006; 28(3): 137-147.

5. Demetri GD, von Mehren $M$, Blanke CD, Van den Abbeele $A D$, Eisenberg B, et al. (2002) Efficacy and safety of imatinib mesylate in advanced gastrointestinal stromal tumors. N Engl J Med 347: 472-480.

6. Hornick JL, Fletcher CD (2007) The role of KIT in the management of patients with gastrointestinal stromal tumors. Hum Pathol 38: 679-687.

7. Zalcberg JR, Verweij J, Casali PG, Le Cesne A, Reichardt P, et al. (2005) Outcome of patients with advanced gastro-intestinal stromal tumours crossing over to a daily imatinib dose of $800 \mathrm{mg}$ after progression on 400 mg. Eur J Cancer 41: 1751-1757.

8. Le Cesne A, Ray-Coquard I, Bui BN, et al. Discontinuation of imatinib in patients with advanced gastrointestinal stromal tumors after 3 years of treatment: an open-label multicentre randomised phase 3 trial. Lancet Oncol. 2010; 11(10): 942-949.

9. Emile JF, Tabone-Eglinger S, Théou-Anton N, Lemoine A (2006) Prognostic value of KIT exon 11 deletions in GISTs. Gastroenterology 131: 976-977.

10. Martin J, Poveda A, Llombart-Bosch A, et al. Deletions affecting codons 557-558 of the c-Kit gene indicate a poor prognosis in patients with completely resected gastrointestinal stromal tumors: a study by the Spanish Group for Sarcoma Research (GEIS). Journal of Clinical Oncology. 2005; 23(25): 6190-6198.

11. ESMO/European Sarcoma Network Working Group (2012) Gastrointestinal stromal tumors: ESMO Clinical Practice Guidelines for diagnosis, treatment and follow-up. Ann Oncol 23 Suppl 7: vii 49-55. 